\title{
CULTURAL LANDSCAPE STRATEGIES FOR RESTORATION OF THE PLAZA DEL CERRO, CHIMAYÓ, NEW MEXICO
}

\author{
M. GONZALES ${ }^{1}$, J. RIVERA ${ }^{1}$, M. AVILA ${ }^{2} \&$ F. UVINA ${ }^{1}$ \\ ${ }^{1}$ University of New Mexico, Community and Regional Planning, USA. \\ ${ }^{2}$ University of New Mexico, College of Education, USA.
}

\begin{abstract}
The Plaza del Cerro at Chimayó is one of the few surviving fortified defensible plazas located within any of the historic land grant communities in contemporary New Mexico, USA. Established as a Spanish colonial settlement in the early 1740s, the plaza plays an important role in understanding the cultural landscape in Chimayó Valley through the organization of the built environment. This article describes the evolution and human settlement morphology of the Plaza del Cerro at Chimayó in the context of the Santa Cruz de la Cañada grant where the site is located. More importantly, we highlight the significance of cultural patrimony that the plaza represents to the Indo-Hispano people of northern New Mexico. The Plaza del Cerro stands as a physical representation of 18th-century town planning principles drawn from the leyes de las indias through a set of ordinances that organized land grant settlements in the Provincia del Nuevo México since the first Spanish colony was established in 1598. In addition, the plaza exhibits and preserves the vernacular architecture engendered by the natural landscape of the Upper Santa Cruz basin. The article provides a historical overview of Plaza del Cerro and outlines preservation and conservation strategies for a community-based approach to accomplish a physical restoration of the site.

Keywords: cultural landscape, defensible plaza, laws of the indies, New Mexico, restoration.
\end{abstract}

\section{CONTEXT AND BACKGROUND}

On 19 April 1695 Governor Diego de Vargas issued a proclamation for the settlement of $L a$ Villa Nueva de Santa Cruz de la Cañada de Españoles Mexicanos del Rey Nuestro Señor Carlos Segundo. His purpose was to create a community land grant to support a growing population of newly arrived settlers from Zacatecas and Mexico City [1]. The founding of the Santa Cruz Grant was strategic not only because of the fertile land and adequate supply of water for irrigation but also because of the need to create a settlement within the Tewa and Tano Pueblo communities that were already established. According to Usner [2], de Vargas 'seemed to have a specific place in mind when he ordered the Tano people off of their land in the Santa Cruz Valley in the late 1600s and assigned them the place called "Zimayo". The unsettled tract of land was probably up the Rio Quemado from the town we call Chimayó today'. With the Tanos relocated to Pueblo Quemado, also known as Córdova today, Governor de Vargas would be free to establish the Santa Cruz Grant under the settlement principles of the leyes de las indias (laws of the indies), which did not permit encroachment on any existing Pueblo Indian lands.

The laws of the indies provided the design principles and land management framework for establishing new town settlements in order to ensure regularity in the built environment within the provinces of New Spain. In the frontier province of New Mexico an added design 
element was the need to provide for the defence of new colonies along the Río del Norte (now the Río Grande) corridor due to relentless attacks by nomadic tribes such as the Navajo, Ute, Comanche, Apache and Kiowa. These nomadic cultures encircled the Río del Norte in all directions and maintained control of large territories for more than two centuries to the point of dictating the pace of Spanish settlement. Governor Tomás Vélez Cachupín's policy in the mid-1700s, which was continued by his successors, was to establish settlements on the fringes of the frontier to serve as a buffer zone between the nomadic tribes and the villas of Santa Cruz, Santa Fe and Albuquerque as well as the Pueblo communities, which also were subjected to raids by the Comanches and other plains' Indians [3].

According to instructions laid out by Veléz Cachupín, pobladores (settler groups) who petitioned for land grants were to build a defensible plaza and construct an acequia irrigation system to support agriculture. The repartimiento or sharing of land was apportioned to each member in the community with a solar or home site on the plaza, as well as a suerte or parcel of irrigated land along the acequia. The land outside of the plaza and the individual farm plots were common for use by all the settlers as an ejido set aside for livestock grazing, hunting, fuel wood gathering as well as public use. The dehesas were additional common grazing areas located within the exterior boundaries of the land grant for access by the settlers. With these incentives in place, settlement growth and expansion essentially followed sources of water, fanning out from the confluence of the Río Grande and the Río Chama on the west, and the Santa Cruz and Embudo rivers on the east.

Contrary to official instructions, settlers often preferred to reside on their own land parcels and not in a village pattern. Mostly, this dispersal pattern was one of multiplying, not enlarging, established places. Initially, settlements consisted of small discontinuing clusters of parajes (encampments) and puestos (outposts), with family groups in charge of their own subsistence and defence [4]. New ranchos and plazas were dispersed in a leapfrogging pattern, even though this made for less defensible settlements, resulting in a cycle of abandonment

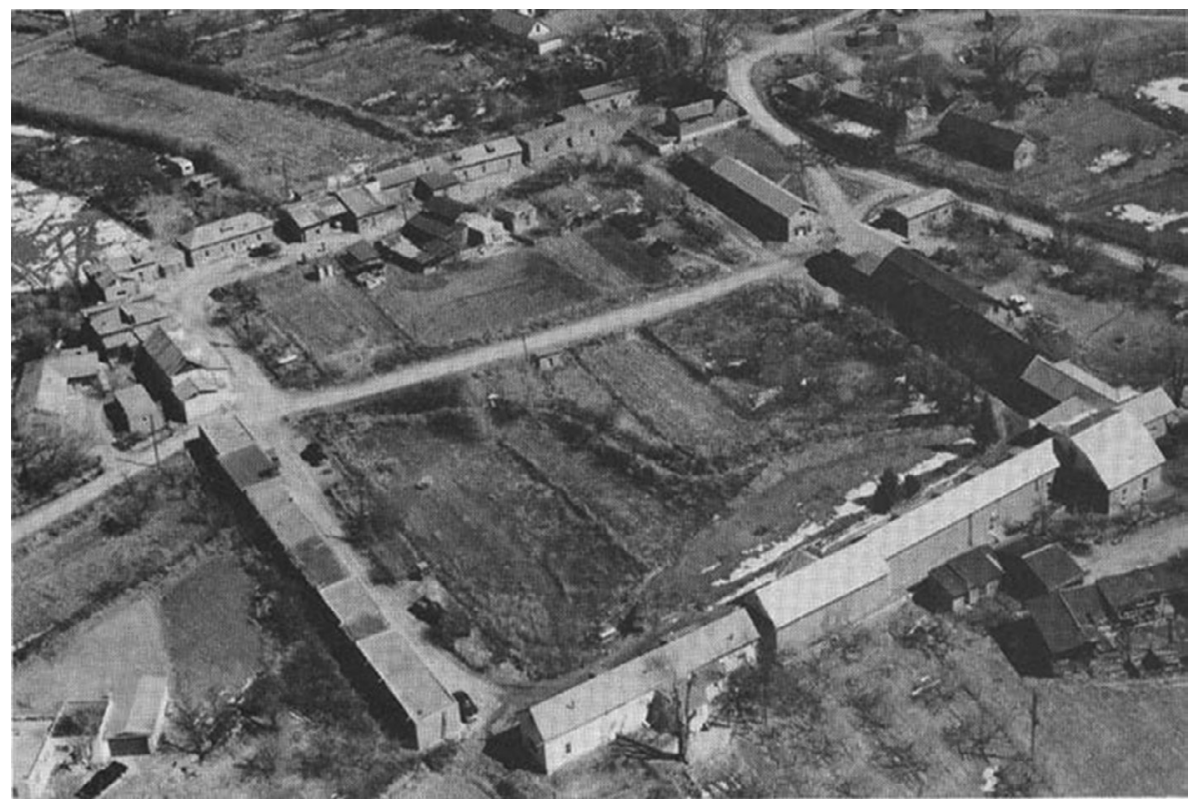

Figure 1: The defensible Plaza del Cerro. Photo by Dick Kent, circa 1960s. 
due to raids by Ute, Navajo, Apache and Comanche bands followed by resettlement after the raids subsided [5]. In many cases, settlers ignored the instructions of governors and Alcaldes to build fortified and walled villages of a grid-plan design; the decentralized placita of ranchos remained the settlement of choice in 19th-century New Mexico as the population moved northwards into the upper Río Chama watershed and other valleys [4] (Fig. 1).

\section{THE PLAZA AT CERRO SURVIVES}

The Plaza del Cerro, originally referred to as 'San Buenaventura de Chimalló, was organized and built as a defensible settlement in the early 1740s [6]. Like other settlements in Northern New Mexico, the plaza was constructed in compliance with the leyes de las indias as a compact defensible plaza with a few modifications to meet the conditions of localized landscape features and climate. Unlike scores of other plazas, however, Cerro survived the Spanish colonial period and represents the vernacular town planning and design style unique to Indo-Hispano settlements of the region prior to World War II. The concepts of vernacular landscape and cultural landscape were increasingly popular with scholars when describing traditional communities of New Mexico and Southern Colorado. For Jackson [7], vernacular 'suggests something countrified, homemade, traditional ... definitions of the word usually suggest that the vernacular dwelling is designed by a craftsman, not an architect, that is built with local techniques, local materials, and with the local environment in mind: its climate, its traditions, its economy - predominantly agricultural'. Every traditional Indo-Hispano settlement in New Mexico is placed within a broader landscape framework defined as 'mercedes' or community land grants along with a complex taxonomy of land and water management systems. In this article, the cultural landscape refers to the location of Plaza del Cerro as a settlement within the larger context of the Santa Cruz de la Cañada land grant located within the Santa Cruz Basin of North Central New Mexico.

By the late 18th and early 19th centuries, the Santa Cruz Valley had expanded to include a network of linked irrigation settlements, known as 'aldeas', such as Santo Niño, La Puebla, Cuarteles, Plaza del Cerro, Potrero and Río Chiquito. The vecinos (residents) of these settlements also had rights and privileges as heredederos (heirs) of the Santa Cruz Land Grant, such as access to the ejidos and dehesas with title to a solar and suerte in the Plaza del Cerro. Throughout the history of the Santa Cruz Grant, a complex social organization and management system evolved to sustain a defensible frontier settlement for many generations of heirs and descendants. These traditional management systems, however, were compromised by and in conflict with American land and water management practices when Nuevo México became part of the United States at the end of the Mexican-American War in 1848.

\section{FORM AND ORGANIZATION OF THE PLAZA DEL CERRO}

The physical form of Plaza del Cerro is a manifestation of the design rules and regulations set forth by the leyes de las indias, but modified to meet the localized climate condition and context as a vernacular town design that today is unique to the American Southwest. Chimayó has evolved as a vernacular landscape that is culturally dynamic, with influences of both Native American and Hispanic heritage through a long period of land tenure [8]. The site environmental conditions and the evolution and morphology of Plaza del Cerro are unique examples of Indo-Hispano town scale urban planning and vernacular architecture drawing from historical analysis.

The Plaza del Cerro plan is organized as a fortified plaza sited for localized climate mitigation of a hot-cold dry arid environment to equally distribute sunlight and shade to all localities in the plaza. The rules stipulated that the four corners of the plaza should be aligned 


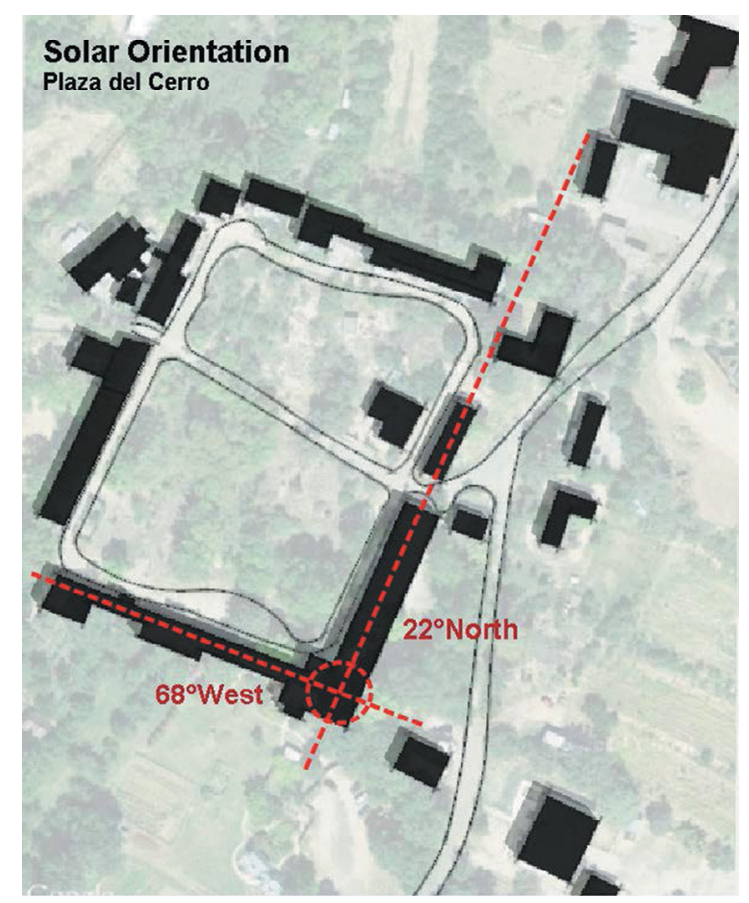

Figure 2: Solar orientation of Plaza del Cerro.

with the four points of a compass to ensure that the plaza would not be directly exposed to the prevailing winds. Overlay morphological mapping of the site was conducted in 2014 by using orthophotography, aerial photography and geographic information system (GIS) data for parcel and building footprints [9]. By mapping the plaza in its true building orientation, the observation can be made that the four points of the plaza are organized to provide adequate sunlight as well as to control cold north-westerly and westerly winds in the winter. For example, the entire plaza is organized such that the East plaza wall is built at a $22^{\circ}$ North orientation and the South plaza wall is built at a $68^{\circ}$ West orientation to allow for equal distribution of sunlight among the residents of Plaza del Cerro (Fig. 2).

As written in the ordinances, each poblador on the plaza would be assigned a solar or a home building plot directly on the plaza. The term 'solar' did mean not only a home site but also the right for shared solar access to all home sites on the plaza. A field examination of the building sites revealed that the plaza accounted for approximately 28 dwellings including the Oratorio de San Buenaventura Chapel. Also, according to the 1822 Mexican census of the Santa Cruz Valley, the population in Plaza de San Buenaventura included 22 families with 92 vecinos totally [10]. The entire plaza site on an area of land slightly smaller than five acres in 1822 would have accounted for a population of 18.4 persons per acre, slightly under the current average density in Boston with approximately 20.9 persons per acre.

Unlike larger plazas such as the nearby Villa de Santa Cruz or the town of Abiquiu on the Río Chama, where the core of the plazas were open and set aside for civic space, the core of the Plaza del Cerro supported small gardens. Just as home sites were allocated and distributed to vecinos in accordance with the laws of the indies, so were the farm plots or suertes. The defensible layout of the settlement suggests that the suertes were allocated inside as well as outside the walls of the plaza. The suertes within the walls of the plaza have historically 


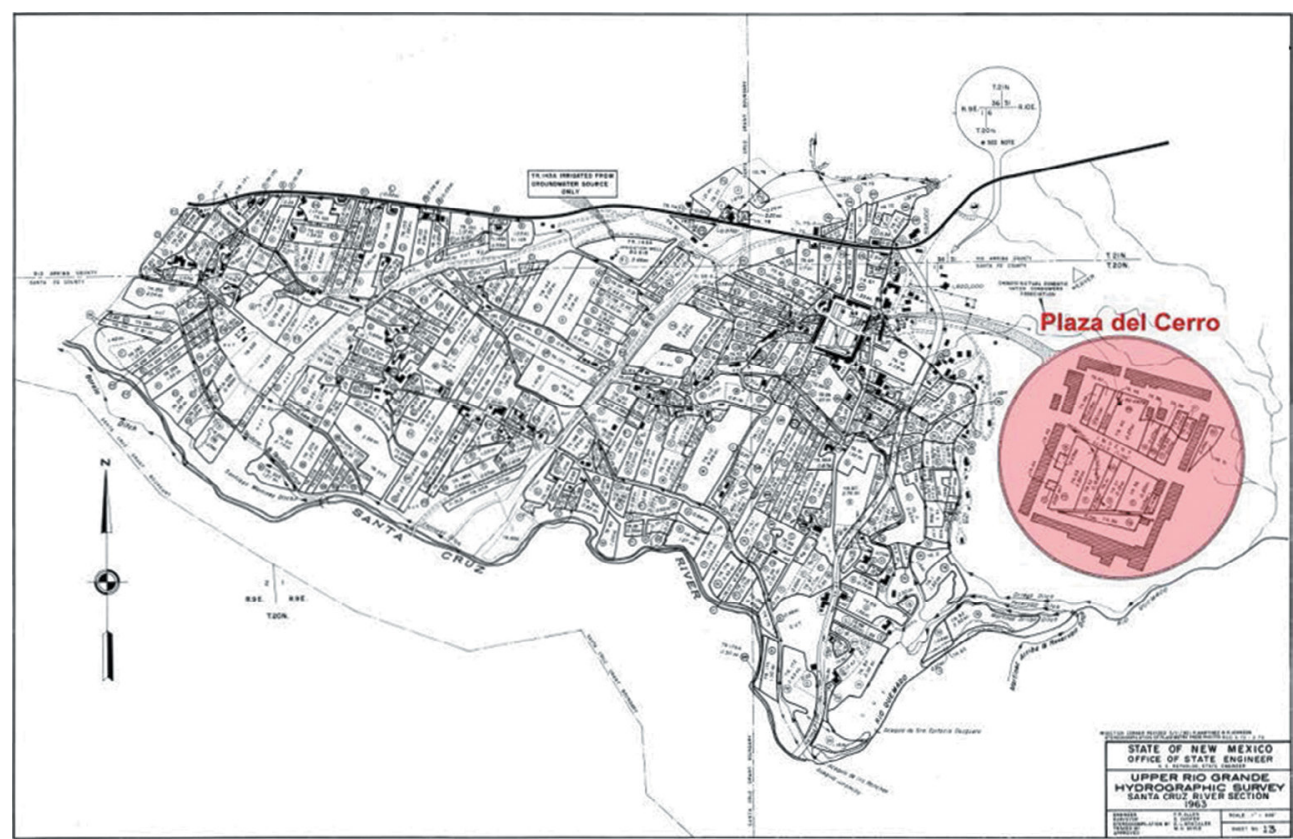

Figure 3: Upper Rio Grande hydrological survey, Santa Cruz River [12].

been supplied by irrigation water from the Acequia de Martínez Arriba which bisects the plaza [11]. According to the 1963 Upper Rio Grande Hydrographic Survey of the Santa Cruz River Section (Fig. 3), the gardens located within Plaza del Cerro consisted of 18 tracts of land accounting for 1.88 acres of irrigated farmland [12]. The irrigated farmland surveyed that year included 0.55 acres of orchard crops, 0.42 acres of garden crops, 0.15 acres of corn, 0.11 acres of irrigated native pasture and 0.64 acres of fallow garden (Fig. 3). Field observation and GIS parcel data survey in June 2014 [9] showed that the suertes in the plaza consisted of 23 parcels of mostly fallow gardens and one single family residential plot occupying 0.09 acres of land.

The survey conducted by the Historic American Building Survey in 1975 [13] revealed that one home dwelling on the northeast wall of the plaza approximately $50 \mathrm{ft}$ in length and $28 \mathrm{ft}$ in width had collapsed. Most of the north wall complex as well as the southwest complex was unoccupied, and structure stabilization was critical before further erasure of the urban form defining the plaza space. Currently there are five residents occupying home sites on the plaza in addition to a bed and breakfast business located on the southwest complex. The Oratorio of San Buenavetura Chapel, located on the southwest complex, was restored in 1954 by women of the confraternity of Our Lady of Carmel, las carmelitas, through the support of a grant from the Spanish Colonial Arts Society [14]. The Chapel is one of the best preserved and maintained structures in the plaza and is still in use by las carmelitas.

The historic urban form based on the leyes de las indias town design still can be seen in the plaza today. However, community-wide efforts to preserve the plaza are reaching a critical point before structural damage to the solar structures further erodes the integrity of the cultural landscape of the town of Chimayó, an important community within the historic Santa Cruz Land Grant. 


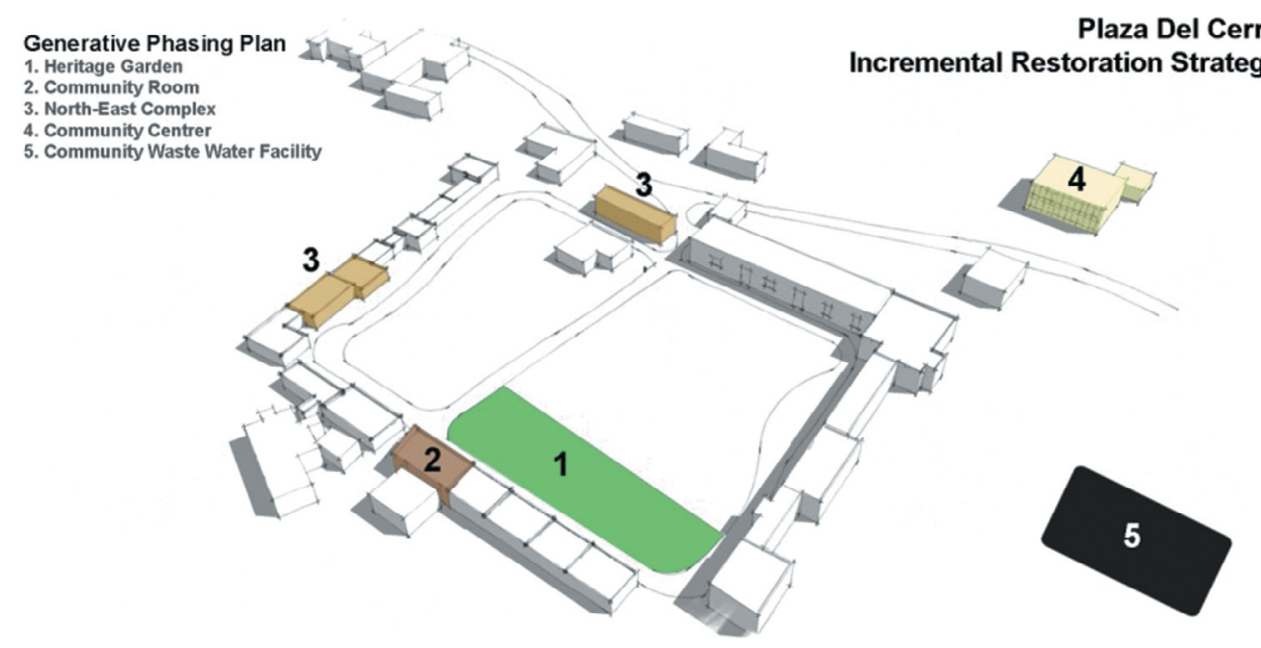

Figure 4: Recommendations for restoration of Plaza del Cerro.

\section{DESIGN STRATEGIES FOR PHYSICAL RESTORATION}

The design strategies for restoration developed in this section of the article were derived from the perspective of a 'generative' and sequential process rather than following a single master plan that is prescriptive and authored by the preservationist vision of an urban designer. The restoration strategy for Cerro should be inclusive and participatory by leveraging the leadership of local mutual aid societies, voluntary associations and other community-based groups. Often preservation efforts recommend a plan for restoration with a top-down process, whereas a focus on community engagement can generate an evolutionary form that grows and transforms incrementally, informed by context and environmental, social and cultural factors [15]. In line with this perspective, the recommendations for restoration of Plaza del Cerro focus on five smaller phased interventions that over time will help to build support and community capacity for sustaining the cultural fabric of the historic plaza (Fig. 4).

\subsection{Phase 1 , heritage garden}

The restoration and maintenance of the suertes or gardens within the plaza are equally important as the maintenance of the physical structures of Plaza del Cerro. The function of the farm plots, acequia and building form collectively articulates a typical community-scale defensible plaza of the 18th century. The first intervention recommended for restoration is a heritage garden on the southwest corner of the plaza. The site location is important because of its proximity to the Capilla de San Buenaventura and the west complex which is entirely uninhabited and allows for more interaction as a community-scale public space. A heritage garden could be planned, designed and implemented by leveraging participants of the community organizations such as the Santa Cruz land grant association, acequia members, the carmelitas and other religious confraternities, as well as youth organizations and local mutual aid societies. The heritage garden could promote cultural programming through educational and cultural events that work to build on maintaining knowledge of local traditional agricultural systems. The heritage garden would provide a space for the larger community of Chimayó to interact with the plaza as a cultural space through a generative process. In addition, the capacity built from the implementation of a heritage garden space would support efforts to 


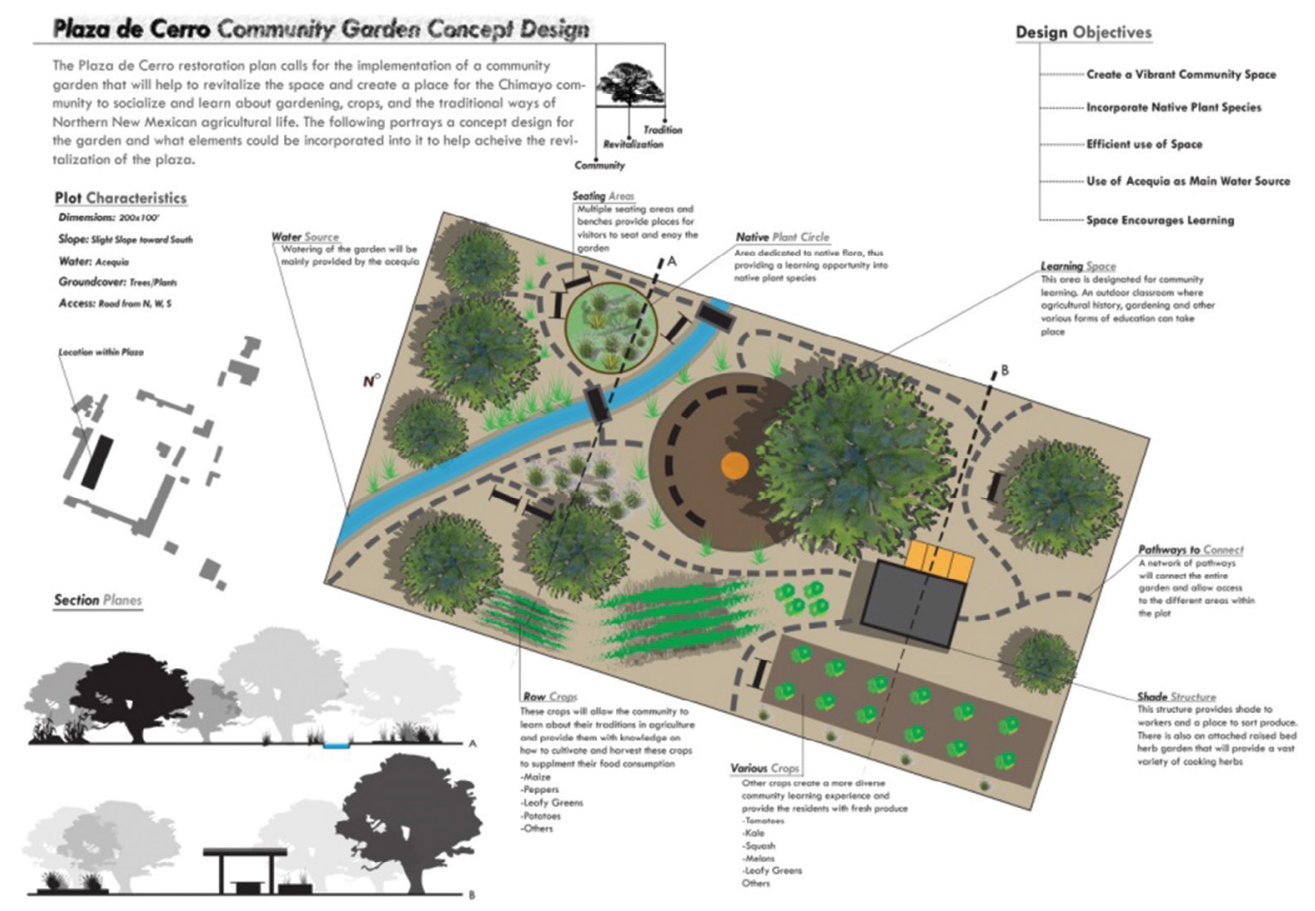

Figure 5: Community heritage garden.

restore other garden sites located in the plaza as well as build organizational capacity of community members to then begin restoration of physical structures that are currently in danger of collapse (Fig. 5).

\subsection{Phase 2, community room on the west complex}

The next phase for restoration recommended for the plaza would be to begin to stabilize and restore a structure for a community meeting room on the west complex of the plaza. The importance of restoring structures on the west complex is to stabilize some of the most threatened structures that could begin to impact the structural integrity of the Capilla de San Buenatventura. The opportunity for restoring the west complex is to create an area on the plaza that can function as a semi-public space for community members to interact with the plaza and the community heritage garden. After preliminary analysis of structural damage to buildings in the west complex, it is critical that the structures directly to the north or south of the chapel be designated as the priority for restoration. The restoration of one of the structures in the west complex into a community room provides additional opportunity to develop cultural programming in the plaza but more importantly connects the broader Chimayó community into the plaza as a social space.

\subsection{Phase 3, restoration of home sites in the north and east complex}

After successful restoration of structures on the west complex as well as expanded community capacity and knowledge base on the community restoration process and techniques, additional community efforts should expand to support the restoration of individual structures on 
the north and east complex. Unlike the west complex which is mainly vacant, the other areas of the plaza are inhabited by residents whose buildings are adjacent to abandoned structures that are in need of stabilization. The effort should then turn to either assisting in stabilizing the structural integrity of historic home sites on the plaza or assisting in efforts by individual owners to fully restore their own residential home sites on the plaza. The west complex of buildings in the plaza should function more as a public space, and the restoration efforts in the remaining areas of the plaza should remain in residential use. However, due to the lack of wastewater infrastructure in the plaza, restoration efforts will need to find a solution to provide community wastewater infrastructure for the plaza to be fully restored with residential and community institutional uses as we propose in phase 5. Currently, the plaza is provided with community water from a community water cooperative known as the Greater Chimayó Mutual Domestic Water Consumers Association.

\subsection{Phase 4, repurposing the John Hyson Memorial School into a community centre}

According to the Chimayó Community Plan by Santa Fe County [16], the primary goal is to 'identify sites and facilities that could be used by local artists, craftsmen, farmers and entrepreneurs to facilitate production, showcase their work and connect them to each other, the community and local and regional markets'. During our own field research, we found many residents who support the community plan recommendation to purchase the John Hyson Memorial School directly east of Plaza del Cerro as part of the restoration efforts, and convert it into a community centre. The repurposing of the old school building could support larger community events and cultural programming. There is a need for additional community gathering spaces, youth activities and a facility that supports capacity building in the town of Chimayó.

A challenge to the restoration of Plaza del Cerro is the ability to restore the site without becoming impacted by tourism. The John Hyson Memorial School provides the potential for cultural programming while still maintaining the living heritage of the plaza. The school is located $300 \mathrm{ft}$ south of the east entrance into the plaza and sits on approximately 1.5 acres of land with several structures including the school building. The building footprint of the old school house is approximately 4,000 square feet which provides flexible space for cultural programming. If plaza restoration is successful, it will be important to have a supporting facility outside the plaza. For example, low-impact guided tours can be managed from this off-site central facility.

\subsection{Phase 5, community wastewater facility}

The overall restoration of Plaza del Cerro is contingent on the development of a community wastewater facility that can support community-scale institutional uses such as community gardens, community space, as well as the re-establishment of residential uses in the plaza. Although community water is provided by the Greater Chimayó Mutual Domestic Water Consumers Association, there is no formal sewer treatment system for homes in Plaza del Cerro. Based on septic tank regulations for residential structures, 'a conventional septic system requires a minimum lot size of 0.75 acres (two bedroom house) or 0.9 acres (three bedroom house) and a minimum setback of $100 \mathrm{ft}$ from private wells and $200 \mathrm{ft}$ from public wells. New development on lots less than $3 / 4$ acre requires high performing septic/wastewater systems that treat wastewater to higher standards' [16]. The septic tank regulations are in place to reduce contamination of underground water resources. Therefore, after the initial interventions are accomplished as recommended in this study, a shared cooperative 
wastewater system should be planned, designed and constructed as part of phase 5 to serve the wastewater capacity of Plaza del Cerro as well as supporting uses. The implementation of a community wastewater system is critical to supporting the restoration of individual residential structures on the plaza. Based on slope and terrain conditions, potential sites for a community wastewater system exist to the south and southwest of the plaza within the proximity of 1,500 ft. Although wastewater treatment may not be in the immediate view of challenges for restoration of the plaza, resolving septic tank challenges remains one of the most critical for preservation of this historic site.

\section{DISCUSSION}

In this paper, we argue that the restoration of Plaza del Cerro should be formulated and implemented by a generative community-based plan supported by the historical and traditional social networks that are already part of the local culture. In the past, master plan-type
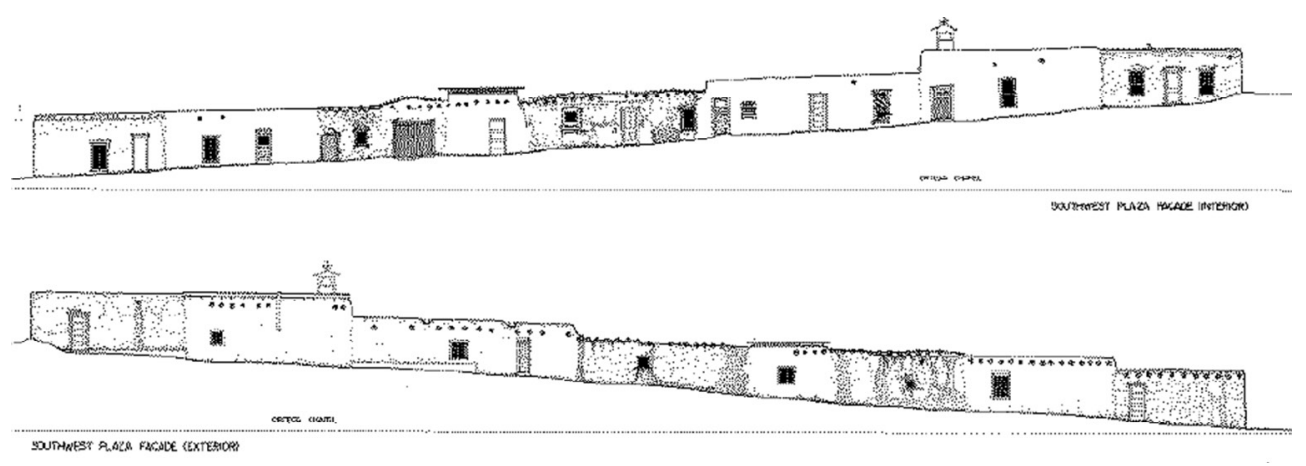

Figure 6: West elevation of Plaza del Cerro, Historic American Buildings Survey 1975.

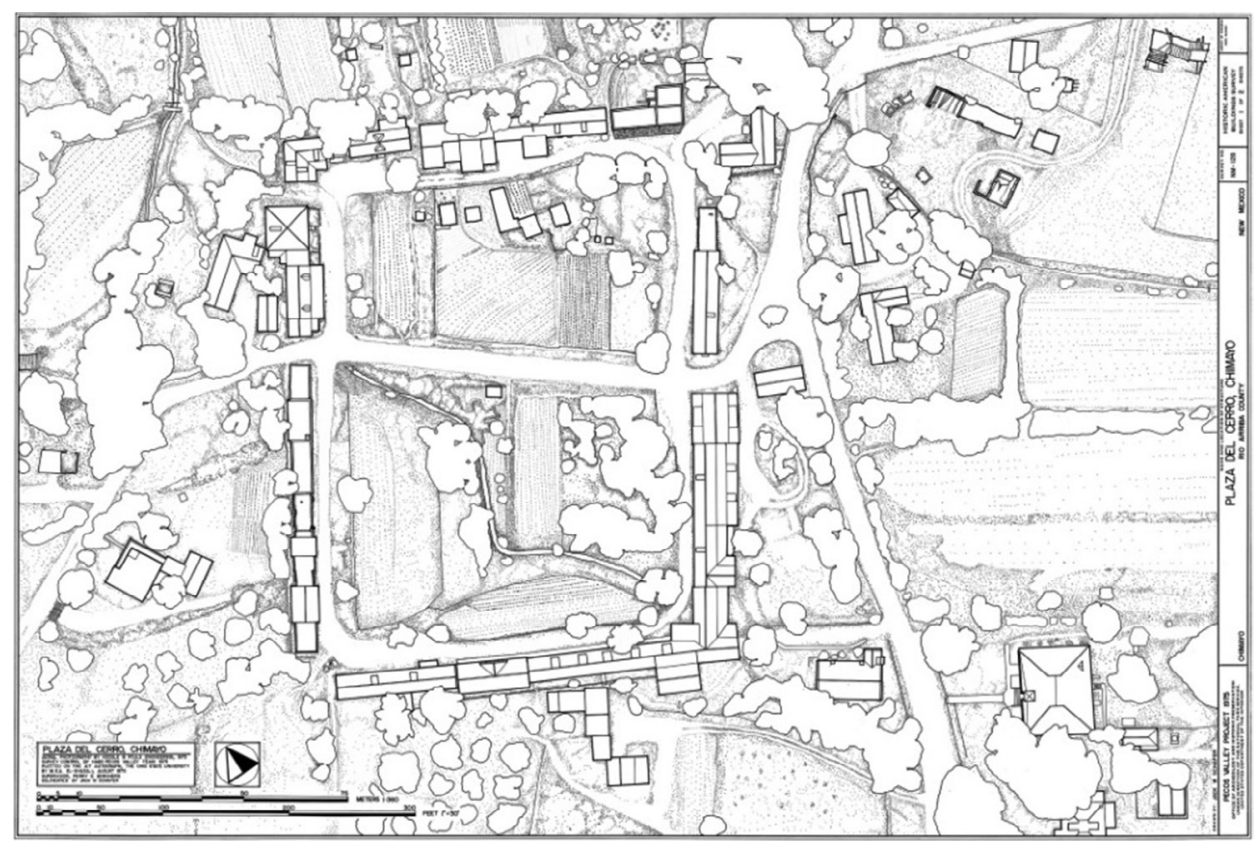

Figure 7: Plan view of Plaza del Cerro, Historic American Buildings Survey 1975. 
restoration efforts have failed because they did not consider leveraging community assets and social capital. We conclude that preservation strategies of the Plaza del Cerro should integrate the concept of voluntary mutual aid that can support a long-term generative restoration effort. The success of physical interventions of the plaza will depend on the success of leveraging institutions such as the carmelitas, acequias, the mutual domestic association, youth groups and other organizations we have identified earlier. From the mobilization of traditional networks, we lay out a process of small-scale generative design interventions for the physical restoration of the plaza that build on reviving gardens, home sites community buildings, as well as critical wastewater infrastructure. The restoration of this cultural landmark of New Mexico will depend on the successful leveraging of community social capital into maintenance and resiliency of Plaza del Cerro as a physical system and as an 18th-century defensible settlement important to the cultural landscape of the Chimayó Valley (Figs. 6 and 7).

\section{REFERENCES}

[1] Rivera, J., Acequia Culture, University of New Mexico Press: Albuquerque, NM, 1998.

[2] Usner, D.J., Sabino's Map: Life in Chimayo's Old Plaza, Museum of New Mexico Press: Santa Fe, NM, p. 54, 1995.

[3] Gonzales, M., The Genizaro land grant settlements of New Mexico. Journal of the Southwest, 56(4), pp. 583-602, 2014. DOI: 10.1353/jsw.2014.0029.

[4] Quintana, F.L., Pobladores: Hispanic Americans of the Ute Frontier, Second Revised Edition of Frances L. Swadesh, 1974. Los Primeros Pobladores, University of Notre Dame Press: South Bend, 1991.

[5] Wozniak, F.E., et al., History and ethnohistory along the Rio Chama. U.S. Army Corps of Engineers: Albuquerque District, Albuquerque, NM, report prepared by John D. Schelberg and Ronald R. Kneebone, 1992.

[6] Usner, D.J., The Plaza del Cerro in Chimayo: settlement and function, Center for Regional Studies, University of New Mexico, Working Paper \#104, 1994.

[7] Jackson, J.B., Discovering the Vernacular Landscape, Yale University Press: New Haven, CT, pp. 85-87, 1994.

[8] Diapsra, D.J., The Conservation and Development of a Historic Vernacular Spanish-American Cultural Landscape: The Village of Chimayo, New Mexico, Master's Thesis, University of Arizona, 1993.

[9] Santa Fe County, Geographic Information Systems Department, Parcel Data, 2011.

[10] Olmsted, V.L., Spanish and Mexican Census of New Mexico; 1750 to 1830, New Mexico Genealogical Society: Albuquerque, NM, pp. 210-211, 1981.

[11] Valdez, A., Potrero Cultural Landscape Report, State Historic Preservation Office, State of New Mexico, 2014.

[12] New Mexico Office of the State Engineer, Upper Rio Grande Hydrographic Survey, Santa Cruz River Section, Sheet 13, 1963.

[13] Historic American Buildings Survey, National Park Service, Department of the Interior, HABS Number NM-128, 1975.

[14] Boyd, E., Repair of Oratorio de San Buenaventura at Chimayo. El Palacio, 62(4), pp. 99-101, 1955.

[15] Mehaffy, M.W., Generative methods in urban design: a progress assessment. Journal of Urbanism, 1(1), pp. 57-75, 2008. DOI: 10.1080/17549170801903678.

[16] Santa Fe County, Chimayó Community Plan, Community Review Draft, p. 63, 2014. 